\title{
PENGARUH PEMBERIAN BAHAN PAKAN SUMBER PROTEIN BERBEDA TERHADAP PERFORMANS AYAM LOKAL PERSILANGAN UMUR 2 - 10 MINGGU \\ Effect Of Feeding With Different Protein Sources On Performance Of Crossbred Local Chicken 2 - 10 Weeks Old
}

\author{
D. Rosita, U. Atmomarsono, W. Sarengat \\ Fakultas Peternakan dan Pertanian Universitas Diponegoro, Semarang
}

\begin{abstract}
ABSTRAK
Tujuan dari penelitian ini adalah mengevaluasi performans ayam lokal persilangan yang diberi bahan pakan sumber protein berbeda. Penelitian ini dilaksanakan pada bulan November 2016 - Januari 2017 di kandang penelitian unggas, Fakultas Peternakan dan Pertanian, Universitas Diponegoro, Semarang. Materi yang digunakan adalah 126 ekor ayam lokal persilangan (unsexed) umur 2-10 minggu dengan bobot badan $129 \pm 6,34 \mathrm{~g}$ $(\mathrm{CV}=5,08 \%)$. Bahan pakan sumber energi yang digunakan adalah jagung dan bekatul, bahan pakan sumber protein yang digunakan adalah bungkil kedelai, tepung ikan, MBM (Meat Bone Meal) dan PMM (Poultry Meat Meal), serta pakan suplemen yang berupa $\mathrm{CaCO}_{3}$. Bahan pakan yang digunakan berbentuk mash (tepung/halus). Pemberian pakan dilakukan dengan metode bebas memilih. Alat lain yang digunakan adalah timbangan digital dengan skala ketelitian $1 \mathrm{~g}$, tempat pakan, tempat minum, termohigrometer. Perlakuan yang diberikan adalah $\mathrm{T} 1=2$ sumber energi (jagung dan bekatul) +2 sumber protein (bungkil kedelai dan tepung ikan), T2 $=2$ sumber energi (jagung dan bekatul) +3 sumber protein (bungkil kedelai dan tepung ikan dan MBM), T3 = 2 sumber energi (jagung dan bekatul) +4 sumber protein (bungkil kedelai, tepung ikan, MBM, dan PMM). Rancangan percobaan yang digunakan yaitu Rancangan Acak Lengkap (RAL) dengan 3 perlakuan dan 7 ulangan, sehingga terdapat 21 unit percobaan, masing-masing unit percobaan terdiri dari 6 ekor ayam. Data diolah menggunakan analisis ragam (uji $\mathrm{F}$ pada taraf 5\%) dan dilanjutkan dengan uji jarak berganda duncan. Hasil menunjukkan bahwa pemberian bahan pakan sumber protein berbeda memberikan pengaruh yang signifikan $(\mathrm{p}<0,05)$ terhadap konsumsi pakan, pertambahan bobot badan, dan konversi pakan ayam lokal persilangan umur $2-10$ minggu.
\end{abstract}

Kata kunci: bahan pakan sumber protein, performans, ayam lokal persilangan.

\section{ABSTRACT}

This research was carried out to determine the effect of feeding with different protein sources on the performance of crossbred local chicken. The research was conducted in November 2016 - January 2017 at the Faculty of Animal Science and Agriculture, Diponegoro University, Semarang. Material used were 126 crossbred local chicken (unsexed) with average body weight $129 \pm 6,34 \mathrm{~g}(\mathrm{CV}=5,08 \%)$. Feedstuffs used in this study were corn, rice bran, fish meal, soybean meal, meat bone meal, Poultry Meat Meal (PMM) and $\mathrm{CaCO}_{3}$. Feeding methods were free choice feeding. The following treatments 
were applied: $T 1=2$ dietary energy source (rice brain and corn) +2 dietary protein source (soybean meal and fish meal); T2 = 2 dietary energy source (rice brain and corn) +3 dietary protein source (soybean meal, fish meal and met bone meal); T3 = 2 dietary energy source (rice brain and corn) +4 dietary protein source (soybean meal, fish meal, meat bone meal and poultry meat meal). This research used Completely Randomized Design with 3 treatments and 7 replicates, there was 21 experimental units, each experimental unit was consisted of 6 bird. Data were analyzed using an analysis of variance (variety of test $F$ at the level of 5\%), followed by Duncan test if there was significant effect of the treatment. Results showed that the treatment of different protein sources influence significantly $(P>0,05)$ on feed intake, body weight gain and feed conversion.

Keywords: protein sources, performance, crossbred local chicken.

\section{PENDAHULUAN}

Ayam lokal persilangan merupakan hasil persilangan antara ayam lokal jantan dengan ayam ras jenis petelur. Ayam ini memiliki pertumbuhan yang relatif lebih cepat dibandingkan dengan ayam lokal biasa, sehingga memiliki umur potong yang relatif pendek. Faktor utama yang mempengaruhi pertumbuhan dari ayam lokal persilangan adalah pakan. Pakan yang diberikan harus sesuai dengan kebutuhan nutrisinya, agar dapat mengoptimalkan performans ayam tersebut, namun kebutuhan nutrisi ayam lokal persilangan ini masih belum diketahui secara pasti, nilainya masih bervariasi dari berbagai sumber. Pada penelitian ayam kampung yang pernah dilakukan oleh Abun et al. (2007) menggunakan kandungan protein kasar 20\% dan energi metabolis 2.900 $\mathrm{kkal} / \mathrm{kg}$, Nurdianto et al. (2015) menggunakan kandungan potein kasar 15 $16 \%$ dan energi metabolis $3.000 \mathrm{kkal} / \mathrm{kg}$, serta penelitian yang pernah dilakukan Kususiyah (2011) yang menggunakan pakan ayam periskok (persilangan ras dan bangkok) dengan kandungan protein kasar $17 \%$.

Protein sangat dibutuhkan untuk unggas, karena berfungsi mensintesis jaringan tubuh atau daging, sebagai molekul physiologis, pembentukan bulu dan produksi telur (Widodo, 2010). Kekurangan protein dalam pakan dapat mengakibatkan pertumbuhan unggas menjadi tidak optimal serta pertumbuhan bulu dapat terganggu, sedangkan kelebihan protein pakan mengakibatkan pakan menjadi tidak efisien. Protein yang berlebih tidak disimpan pada tubuh dalam bentuk yang nyata, serta protein merupakan bagian ransum termahal, sehingga tidak akan efisien jika diberikan secara berlebihan (Anggorodi, 1985).

Penyediaan pakan sumber protein yang berbeda dengan metode pemberian pakan bebas memilih bertujuan untuk mengetahui bahan pakan sumber protein yang disukai oleh ayam kampung super, serta untuk mengukur kebutuhan nutrisi ayam kampung super. Unggas diketahui memiliki kemampuan untuk menentukan kebutuhan nutrisinya sendiri (Fanatico et al., 2013). Beberapa penelitian menunjukkan bahwa unggas dapat memenuhi kebutuhan nutrisinya sendiri melalui sistem pemberian pakan bebas memilih. Pemberian pakan dengan sistem ini biasanya satu tempat pakan diisi dengan satu macam bahan pakan, sehingga memungkinkan unggas untuk mengkonsumsi bahan pakan yang memiliki 
palatabilitas tinggi dan sesuai dengan kebutuhan nutrisinya (Blair, 2008; Rack et al., 2009; Arroyo et al., 2014).

Konsumsi pakan ayam dipengaruhi oleh kandungan protein dan energi di dalam pakan. Konsumsi pakan lebih rendah pada ayam yang diberi pakan dengan kandungan energi yang rendah (Dairo et al., 2010). Pertambahan bobot badan yang optimal dapat diperoleh dengan memberikan pakan yang memiliki zat nutrisi yang seimbang. Zat nutrisi yang ada dalam pakan sangat mempengaruhi perfomans ayam. Konversi pakan dipengaruhi oleh konsumsi pakan dan bobot badan, karna konversi pakan yaitu, banyaknya konsumsi pakan yang digunakan untuk menaikkan $1 \mathrm{~kg}$ bobot badan ayam kampug super (Mointi, 2014).

Tujuan dari penelitian ini adalah mengevaluasi performans ayam lokal persilangan yang diberi bahan pakan sumber protein berbeda. Hasil penelitian ini diharapkan dapat memberikan informasi mengenai kebutuhan protein kasar dan energi metabolis ayam lokal persilangan.

\section{MATERI DAN METODE}

Penelitian tentang pengaruh pemberian pakan dengan bahan pakan sumber protein yang berbeda terhadap performans ayam lokal persilangan pada umur 2 - 10 minggu dilaksanakan pada bulan November 2016 - Januari 2017 di kandang penelitian unggas, Fakultas Peternakan dan Pertanian, Universitas Diponegoro, Semarang.

Materi yang digunakan dalam penelitian ini adalah 126 ekor ayam lokal persilangan (unsexed) umur $2-10$ minggu dengan bobot badan $129 \pm 6,34 \mathrm{~g}(\mathrm{CV}=$ $5,08 \%$ ) dari peternakan Astak, Temanggung, Jawa Tengah. Kandang tipe panggung dengan alas kawat yang dibagi menjadi 21 unit percobaan dengan masingmasing unit percobaan berisi 6 ekor ayam. Bahan yang digunakan dalam penelitian ini adalah larutan gula untuk DOC yang baru datang, air minum, desinfektan serta vitamin, sedangkan vaksin yang diberikan adalah vaksin ND (Newcastle Desease) dan gumboro A.

Tabel 1. Kandungan Nutrisi Bahan Pakan Berdasarkan Kering Udara

\begin{tabular}{|c|c|c|c|c|c|c|c|}
\hline Bahan Pakan & $\mathrm{EM}^{\mathrm{d}}$ & $\mathrm{PK}^{\mathrm{a}}$ & $\mathrm{SK}^{\mathrm{a}}$ & $\operatorname{Lisin}^{\mathrm{c}}$ & Metionin $^{c}$ & $\mathrm{Ca}^{\mathrm{b}}$ & $\mathrm{P}^{\mathrm{a}}$ \\
\hline & (kkal/kg) & & & & & & \\
\hline Jagung Kuning & 3.796 & 6,54 & 2,15 & 0,34 & 0,21 & 0,03 & 0,20 \\
\hline Bekatul & 3.643 & 10,86 & 7,55 & 0,58 & 0,22 & 0 & 1,53 \\
\hline Bungkil kedelai & 3.213 & 45,76 & 3,97 & 2,98 & 0,7 & 0,05 & 0,39 \\
\hline Tepung ikan & 2.986 & 31,51 & 1,82 & 6,56 & 2,56 & 6,42 & 2,04 \\
\hline MBM & 2.770 & 58,49 & 1,07 & 3,45 & 0,75 & 9,08 & 4,14 \\
\hline PMM & 3.555 & 43,08 & 7,82 & 1,19 & 0,54 & 1,01 & 2,12 \\
\hline $\mathrm{CaCO}_{3}$ & 0 & 0 & 0 & 0 & 0 & 80 & 0 \\
\hline
\end{tabular}

Sumber :

a. Hasil Analisis Proksimat di PT. Sidomuncul, Ungaran (2016).

b. Hasil Analisis di Laboratorium Ilmu Nutrisi dan Pakan, Fakultas Peternakan dan Pertanian, Universitas Diponegoro,Semarang (2016).

c. Hartadi (1980).

d. Hasil Perhitungan menggunakan Uji Bomb Calorimeter di Laboratorium Ilmu Nutrisi dan Pakan, Fakultas Peternakan dan Pertanian, Universitas Diponegoro (2016).

Bahan pakan sumber energi yang bahan pakan sumber protein yang digunakan adalah jagung dan bekatul, digunakan adalah bungkil kedelai, tepung 
ikan, MBM (Meat Bone Meal) dan PMM (Poultry Meat Meal), serta pakan sumplemen yang berupa $\mathrm{CaCO}_{3}$. Bahan pakan yang digunakan berbentuk mash (tepung/halus). Alat lain yang digunakan adalah timbangan digital dengan skala ketelitian $1 \mathrm{~g}$, tempat pakan, tempat minum, termohigrometer.

Racangan percobaan yang digunakan dalam penelitian ini yaitu Rancangan Acak Lengkap (RAL) dengan 3 perlakuan dan 7 ulangan, sehingga terdapat 21 unit percobaan, masing-masing unit percobaan terdiri dari 6 ekor ayam. Perlakuan yang diberikan adalah:

$\mathrm{T} 1=2$ sumber energi (jagung dan bekatul) +2 sumber protein (bungkil kedelai dan tepung ikan).

$\mathrm{T} 2=2$ sumber energi (jagung dan bekatul) +3 sumber protein (bungkil kedelai tepung ikan dan MBM)

$\mathrm{T} 3=2$ sumber energi (jagung dan bekatul) +4 sumber protein (bungkil kedelai, tepung ikan, MBM, dan PMM).

Memasukkan DOC ayam lokal persilangan yang baru datang, serta memberi minum berupa larutan gula, guna mengembalikan stamina ayam setelah perjalanan jauh. DOC diletakan pada satu kandang yang sama dan diberi pakan komersial (BR1 AJ dari PT. Charoen Pokphand Indonesia) selama 10 hari. Pemberian pakan dilakukan dengan metode pakan bebas memilih ad libitum dan pemberian minum dilakukan ad libitum. Hari ke-2 dilakukan pemberian vaksin Newcastle Desease (ND) untuk pencegahan penyakit tetelo dengan metode tetes mata. Hari ke-15 diberi vaksin gumboro A melalui air minum. Setelah berumur 11 hari, ayam dipindahkan ke dalam masingmasing unit percobaan dan mulai dilakukan adaptasi perlakuan selama 3 hari. Parameter yang diambil meliputi:

a. Konsumsi pakan selama penelitian, merupakan jumlah pakan yang diberikan dikurangi dengan jumlah pakan yang tersisa.

b. Pertambahan bobot badan per ekor selama penelitian, diperoleh dengan cara menimbang ayam pada awal penelitian dan akhir penelitian. Rumus:

PBB $($ g/ekor $)=$ BB akhir penelitian $\mathrm{BB}$ awal penelitian

c. Konversi ransum, konversi ransum merupakan jumlah pakan yang digunakan untuk menaikkan per satuan bobot badan ternak ayam.

Konversi ransum=

$\frac{\text { Konsumsi ransum (g/ekor) }}{\text { Pertambahan bobot badan (g/ekor) }}$

Data yang diperoleh diolah menggunakan analisis ragam (uji $\mathrm{F}$ pada taraf 5\%) untuk mengetahui pengaruh perlakuan terhadap parameter dandilanjutkan uji jarak berganda duncanuntuk mengetahui perbedaan antar perlakuan (Steel dan Torrie, 1995).

\section{HASIL DAN PEMBAHASAN}

Berdasarkan hasil penelitian mengenai pemberian bahan pakan sumber protein berbeda terhadap performans ayam lokal persilangan umur $2-10$ minggu dapat dilihat pada Tabel 2. Data pada Tabel 2. menunjukkan bahwa pemberian bahan pakan sumber protein berbeda berpengaruh nyata terhadap performans ayam lokal persilangan umur 2 - 10 minggu. Tabel 3 . menunjukkan data pendukung. 


\section{Konsumsi Pakan}

Rata-rata konsumsi pakan ayam kampung super umur $2-10$ minggu berkisar 2935,27 - 3249,51 g/ekor atau 366,91 - 406,19 g/ekor/minggu atau 52,41 - 58,03 g/ekor/hari. Konsumsi pakan ayam kampung super ini lebih tinggi jika dibandingkan dengan hasil penelitian Kususiyah (2011) yaitu 2699,20 g/ekor dan rata-rata konsumsi per hari yaitu 38,56 g/ekor, pakan yang diberikan berupa konsentrat, jagung giling dan dedak halus (ransum oplosan) dengan kandungan protein $17 \%$.

Hasil analisis ragam menunjukkan bahwa pemberian bahan pakan sumber protein berbeda berpengaruh nyata $(\mathrm{P}<0,05)$ terhadap konsumsi pakan. T1 dan T2 menunjukkan hasil yang tidak berbeda nyata, sedangkan T3 menunjukkan hasil yang berbeda nyata $(\mathrm{P}<0,05)$ terhadap $\mathrm{T} 1$ dan T2. Konsumsi pakan yang tidak berbeda nyata diikuti dengan konsumsi energi yang tidak berbeda nyata pula, yang dapat dilihat pada Tabel 3.

Tabel 2. Konsumsi Pakan, Pertambahan Bobot Badan dan Konversi Pakan Ayam Lokal Persilangan selama 2 - 10 Minggu.

\begin{tabular}{lccc}
\hline \multirow{2}{*}{ Parameter } & \multicolumn{3}{c}{ Perlakuan } \\
\cline { 2 - 4 } & $\mathrm{T} 1$ & $\mathrm{~T} 2$ & $\mathrm{~T} 3$ \\
\hline Konsumsi Pakan (g/ekor) & $2.935,27^{\mathrm{b}}$ & $3.015,81^{\mathrm{b}}$ & $3.249,51^{\mathrm{a}}$ \\
Pertambahan Bobot Badan (g/ekor) & $693,47^{\mathrm{b}}$ & $760,67^{\mathrm{b}}$ & $886,93^{\mathrm{a}}$ \\
Konversi Pakan & $4,33^{\mathrm{b}}$ & $4,00^{\mathrm{ab}}$ & $3,67^{\mathrm{a}}$ \\
\hline
\end{tabular}

Keterangan: Superskrip berbeda pada baris yang sama menunjukkan perbedaan nyata $(\mathrm{P}<0,05)$.

Konsumsi pakan T3 lebih tinggi jika dibandingkan dengan perlakuan yang lain. Semakin tinggi konsumsi pakan pada setiap perlakuan diikuti juga dengan konsumsi nutrisi yang semakin meningkat pula. Tingginya konsumsi pakan dan konsumsi nutrisi pada T3 disebabkan oleh banyaknya bahan pakan sumber protein yang disediakan, sehingga ayam mempunyai kesempatan mengkonsumsi pakan yang lebih tinggi jika dibandingkan dengan perlakuan yang lain. Menurut Ariesta et al. (2015) menurunnya konsumsi nutrisi merupakan akibat dari menurunya kandungan energi dan protein ransum. Perbedaan tingkat konsumsi nutrisi ini dapat mempengaruhi performans ayam. Arabi (2015) menyatakan bahwa perbedaan tingkat protein dalam pakan memiliki pengaruh yang nyata terhadap performans ayam, tingkat protein pakan yang rendah pada pakan ayam akan menurunkan performans ayam sedangkan peningkatan kadar protein pakan, akan meningkatkan kinerja pertumbuhan dan karateristik karkas.

Tabel 3. Efisiensi Penggunaan Protein dan Energi Pakan Ayam Lokal Persilangan selama 2-10 Minggu.

\begin{tabular}{lccc}
\hline \multirow{2}{*}{ Parameter } & \multicolumn{3}{c}{ Perlakuan } \\
\cline { 2 - 4 } & $\mathrm{T} 1$ & $\mathrm{~T} 2$ & $\mathrm{~T} 3$ \\
\hline Konsumsi Protein (g/ekor/hari) & $7,65^{\mathrm{c}}$ & $9,57^{\mathrm{b}}$ & $11,30^{\mathrm{a}}$ \\
Konsumsi Energi (g/ekor/hari) & $182,07^{\mathrm{b}}$ & $185,99^{\mathrm{b}}$ & $202,24^{\mathrm{a}}$ \\
Kecernaan Protein (\%) & $75,93^{\mathrm{a}}$ & $76,33^{\mathrm{a}}$ & $78,10^{\mathrm{a}}$ \\
Retensi N (g) & $1,15^{\mathrm{a}}$ & $1,18^{\mathrm{a}}$ & $1,61^{\mathrm{b}}$ \\
\hline
\end{tabular}


Keterangan: Superskrip berbeda pada baris yang sama menunjukkan perbedaan nyata $(\mathrm{P}<0,05)$.

Bahan pakan yang banyak konsumsi pakan, jumlah konsumsi pakan dikonsumsi disetiap perlakuan adalah yang relatif sama akan menghasilkan bekatul. Hal ini berbeda dengan penelitian pertambahan bobot badan yang tidak jauh Rack et al. (2009) yang menyatakan bahwa pada sistem pemberian pakan bebas memilih, unggas cenderung memilih bahan pakan jagung. Menurut Widodo (2010) bekatul memiliki palatabilitas yang cukup baik.

\section{Pertambahan bobot badan}

Rata-rata pertambahan bobot badan ayam lokal persilangan umur 2 - 10 minggu yang diberikan bahan pakan sumber protein berbeda yaitu 693,47 - 886,93 g/ekor atau $86,68-110,87$ g/ekor/minggu. Hasil tersebut lebih tinggi jika dibandingan dengan penelitian Kususiyah (2011) bahwa ayam lokal persilangan yang dipelihara 2 10 minggu menghasilkan pertambahan bobot badan $684,18 \mathrm{~g}$ /ekor, serta penelitian Munira et al. (2016) yang menghasilkan pertambahan bobot badan 70,94 - 79,31 g/ekor/minggu.

Hasil analisis ragam menunjukkan bahwa pemberian bahan pakan sumber protein berbeda berpengaruh nyata $(\mathrm{P}<0,05)$ terhadap pertambahan bobot badan ayam lokal persilangan. T1 dan T2 menunjukkan hasil yang tidak berbeda nyata, sedangkan T3 menunjukkan hasil yang berbeda nyata $(\mathrm{P}<0,05)$ terhadap $\mathrm{T} 1$ dan $\mathrm{T} 2$. Tingginya angka pertambahan bobot badan ini dipengaruhi oleh konsumsi pakan yang tinggi pula. Munira et al. (2016) menyatakan bahwa semakin tinggi konsumsi pakan diikuti dengan semakin tinggi pula rata-rata pertambahan bobot badan. Hal yang sama juga dinyatakan oleh Mointi (2014) yang menyatakan bahwa pertambahan bobot badan dipengaruhi oleh berbeda juga.

Bahan pakan sumber protein yang disediakan pada T3 lebih banyak daripada perlakuan yang lain. Hal tersebut mendorong pertambahan bobot badan ayam pada T3 lebih tinggi. Konsumsi nutrisi lebih tinggi jika dibandingkan dengan perlakuan yang lain, diikuti dengan retensi nitrogen dan kecernaan protein yang tinggi pula, dapat dilihat pada Tabel 3. Tingginya angka retensi nitrogen ini menyebabkan semakin tingginya angka pertambahan bobot badan. Ariesta et al. (2015) menyatakan bahwa meningkatnya angka retensi nitrogen dapat menyebabkan meningkatnya angka pertumbuhan, karena semakin banyak nitrogen yang digunakan untuk menyusun komponen tubuh. Meningkatnya angka kecernaan protein akan menyebabkan tingginya angka retensi protein yang dapat dimanfaatkan oleh tubuh, hal ini berpengaruh terhadap pertumbuhan yang ditandai dengan meningkatnya bobot badan (Fanani et al., 2014).

T3 dan T2 menghasilkan pertambahan bobot badan yang lebih tinggi dibandingkan dengan T1. Hal ini disebabkan karena bahan pakan pada T3 dan T2 mengandung kandungan nutrisi yang lebih lengkap dari pada T1. T1 hanya mengandung 2 sumber protein yaitu bungkil kedelai dan tepung ikan, T2 mengandung 3 sumber protein yaitu bungkil kedelai, tepung ikan dan MBM serta T3 mengandung 4 sumber protein yaitu bungkil kedelai, tepung ikan, MBM, dan PMM. Pemberian protein pada pakan ayam lokal persilangan harus benar-benar 
seimbang dan sesuai dengan kebutuhan nutrisinya. Menurut Anggorodi (1985) kekurangan protein dalam pakan dapat mengakibatkan pertumbuhan unggas menjadi tidak optimal, sedangkan kelebihan protein pakan mengakibatkan pakan menjadi tidak efisien. Widodo (2010) menyatakan bahwa protein sangat dibutuhkan untuk ternak, karena berfungsi mensintesis jaringan tubuh atau daging, sebagai molekul physiologis, pembentukan bulu dan produksi telur.

Bahan pakan sumber protein yang berupa MBM dan PMM yang terdapat pada T3 menjadi pendorong tingginya angka pertambahan bobot badan, dimana bahan pakan ini merupakan bahan pakan sumber protein hewani yang memiliki banyak kelebihan, dengan kandungan asam amino yang seimbang dan sangat dibutuhkan oleh unggas. MBM dan PMM merupakan bahan pakan sumber protein hewani yang mengandung protein yang tinggi, selain itu juga kaya akan kalsium (Ca) dan fosfor (P). Penelitian yang dilakukan oleh Caires (2010) menyatakan bahwa ransum dengan campuran MBM dan PMM memiliki bobot badan dan konversi pakan yang baik. Bahan pakan sumber protein dengan asam amino yang tinggi dan seimbang akan meningkatkan performans ayam (Wahju, 2004).

\section{Konversi pakan}

Konversi pakan ayam lokal persilangan umur 2 - 10 yang diberi bahan pakan sumber protein berbeda yaitu berkisar 3,67 - 4,33. Sama seperti penelitian yang dilakukan oleh Kususiyah (2011) ayam kampung persilangan yang diberi pakan konsentratjagung giling dan dedak halus (ransum oplosan) dengan kandungan protein $17 \%$ memiliki konversi 3,95. Angka konversi pakan menunjukkan berapa banyak pakan yang digunakan untuk menaikan satu persatuan bobot badan ternak. Semakin rendah angka konversi pakan, maka semakin baik pula ayam mengkonversi pakan menjadi daging.

Hasil analisis ragam menunjukkan bahwa pemberian bahan pakan sumber protein berbeda berpengaruh nyata $(\mathrm{P}<0,05)$ terhadap konversi pakan ayam lokal persilangan. T1 menunjukkan hasil yang berbeda nyata $(\mathrm{P}<0,05) \quad$ denganT3, sedangkan $\mathrm{T} 2$ tidak berbeda nyata dengan T1 dan T3.

T3 memiliki angka konversi yang lebih rendah dibandingkan dengan perlakuan lain. Rendahnya angka konversi ini didorong oleh konsumsi nutrisi yang tinggi, baik itu konsumsi energi maupun juga konsumsi protein, dapat dilihat pada Tabel 3. Ransum yang baik adalah ransum yang dapat memenuhi kebutuhan nutrisiayam dan lebih efisiensi dalam penggunaannya. Menurut Arabi (2015) perbedaan tingkat protein dalam pakan memiliki pengaruh yang nyata terhadap performans ayam, peningkatan kadar protein pakan, akan meningkatkan kinerja pertumbuhan dan karateristik karkas.

Tingginya angka konversi pakan pada T1 dan T2 disebabkan konsumsi nutrisi yang rendah, sehingga sedikit nutrisi yang dapat dimanfaatkan untuk pertumbuhan ayam. Konversi pakan dipengaruhi oleh kandungan pakan/ransum yang diberikan, dimana T3 memiliki bahan pakan sumber protein yang lebih beragam dan lebih lengkap jika dibandingkan dengan T1 dan T2. Menurut Fanani et al. (2014) konversi pakan dipengaruhi oleh konsumsi pakan, berat badan, kandungan nutrisi ransum, semakin besar angka konversi pakan, maka semakin kurang ekonomis penggunaan pakan tersebut. 


\section{KESIMPULAN}

Pemberian bahan pakan sumber protein berbeda memberikan pengaruh yang signifikan terhadap konsumsi pakan, pertambahan bobot badan, dan konversi pakan ayam lokal persilangan umur $2-10$ minggu. Pemberian pakan dengan sumber energi dan sumber protein nabati yang sama, namun dengan sumber protein hewani yang semakin bervariasi, dapat meningkatkan performans ayam lokal persilangan.

\section{DAFTAR PUSTAKA}

Abun, D. Rusmana dan D. Saefulhadjar. 2007. Efek pengolahan limbah sayuran secara mekanik terhadap nilai kecernaan pada ayam kampung super. J. Ilmu Ternak. 7 (2) : 81 86.

Anggorodi, R. 1985. Ilmu Nutrisi Makanan Ternak Unggas. Universitas Indonesia Press, Jakarta.

Arabi, S. A. M. 2015. The effects of different protein and energy levels on broilers performance under hot climatic conditions. J. Innov. Agric. and Bio Res. 3 (1) : 19 - 28.

Ariesta, A. H., I. G. Mahardika dan A. M. K Dewi. 2015. Pengaruh level energi dan protein ransum terhadap penampilan ayam kampung umur 0 10 minggu. Majalah Ilmu Peternakan. 18 (3) : 89 - 94.

Arroyo, J., L. F. Lamothe, J. P. Dubois, F. Lavigne, M. Bijja, dan C. Molette. 2014. The influence of choice feeding and cereal type (corn or triticale) during the finishing period on performance of mule ducks. J. Poult. Sci. 93 (9): 2220 - 2226.
Blair, R. 2008. Nutrition and Feeding of Organic Poultry. CABI, London.

Caires, C. M., E. A. Fernandes, N. S. Fagundes, A. P. Carvalho, M. P. Maciel dan B. R. Oliveira. 2010. The use of animal byproducts in broiler feeds. Use of animal coproducts in broilers diets. Brazilian J. Poult. Sci.. 12 (1): 41 - 46.

Catanese, F., H. R. Ganduglia, J. J. Villalba dan R. A. Distel. 2015. Free availability of high-energy foods led to energy over-ingestion and protein under ingestion in choice-fed broilers. J. Anim Sci. 86 (12): 1.000 -1.009 .

Dairo, F. A. S., A. O. K. Adesehinwa, T. A. Oluwasola dan J. A. Oluyemi. 2010. High and low dietary energy dan protein levels for broiler chickens. J. Agric. Res. 5 (15): 2030 - 2038.

Fanani, A. F., N. Suthama dan B. Sukamto. 2014. Retensi nitrogen dan konversi pakan ayam lokal persilangan yang diberi ekstrak umbi dahlia (Dahlia variabilis) sebagai sumber insulin. J. Sains Peternakan. 12 (2) : 69 - 75.

Fanatico, A. C., V.B. Brewer, C. M. O. Hanning, D. J. Donoghue dan A. M. Donoghue. 2013. Free-choice feeding of free-range meat chickens. J. Appl. Poult. Res. 22 (4): 750 758.

Iskandar, S. 2011. Laying performance of wareng chicken under free choice feeding and different cage density. Media Peternakan. 34 (1): 58 - 63.

Kususiyah. 2011. Performans pertumbuhan ayam peraskok sebagai ayam potong belah empat serta nilai income over feed and chick cost. J. Sain Peternakan Indonesia. 6 (2) : 83 87. 
Mointi, D. 2014. Produktivitas Ayam Kampung Super Periode Starter yang Diberi Pakan Komersial. Fakultas Peternakan, Universitas Negeri Gorontalo. (Thesis).

Munira, S., L. O. Nafiu, A. M. Tasse. 2016. Performans ayam kampung uper pada pakan yang disubstitusi dedak padi fermentasi dengan fermentor berbeda. JITRO. 3 (2) : 21 - 29.

Nurdianto, M., C. S. Utama dan S. Mukodiningsih. 2015. Total jamur, jenis kapang, dan khamir pellet ayam kampung super dengan penambahan berbagai level pollard berprobiotik. J. Agripet. 15 (2): 79 84.

Rack, A. L., K. G. S. Lilly, K. R. Beaman, C. K. Gehring dan J. S. Moritz. 2009. The effect of genotype, choice feeding, and season on organically reared broiler fed diets devoid of synthetic methionine. J. Appl. Poult. Res. 18 (1): 54 - 65.

Steel, R. G. D, dan J. H Torrie. 1995. Prinsip dan Prosedur Statistika suatu Pendekatan Biomatrik. Cetakan ke2. PT. Gramedia Pustaka Utama, Jakarta.

Wahju, J. 2004. Ilmu Nutrisi Unggas.

Cetakan ke-5. Gadjah Mada University Press, Yogyakarta.

Widodo, E. 2010. Nutrisi dan Teknik Pemeliharaan Ayam Organik. Universitas Brawijaya Press, Malang. 